\title{
Marketing Practice of Small and Medium Enterprises (SMEs): Perspective from a Developing Country
}

\author{
Ogundeji Jolasinmi Kayode Ogundele ${ }^{1}$ \\ Waidi Adeniyi Akingbade ${ }^{2}$ \\ Rahmon Olawale Saka ${ }^{3}$ \\ Ayobami Folarin Elegunde 4 \\ Azeez Adekunle Aliu ${ }^{5}$ \\ Department Of Business Administration and Management Technology, \\ Lagos State University, Ojo, Lagos, Nigeria. \\ 1E-mail: oludelekayode@yahoo.co.uk Tel.: +2348055415293. \\ 2 E-mail: akinwaidi@yahoo.com Tel.: +2348030500622. \\ 3E-mail: sakarahmon@yahoo.com Tel.: +2348056134743. \\ 4E-mail: emolomo2003@yahoo.com Tel.: +2348029087821. \\ 5E-mail: adekunlealiu@yahoo.com Tel.: +2348023916659.
}

Doi:10.5901/mjss.2013.v4n3p243

\begin{abstract}
This paper focuses on marketing practice of SMEs in Nigeria. The specific key learning objectives of the paper are; to highlight the strategic importance of SMEs in economic development of any economy; to sketch the patterns of Government support programmes for development of SMEs in Nigeria and Past Empirical Studies of SMEs performance in Nigeria; to highlight the importance SMEs for survival and continued growth of Nigeria Economy; to highlight the impact of environmental factors on marketing practice of SMEs; to establish the extent to which marketing practice of SMEs in Nigeria conforms with marketing principles and functions. The Nigeria marketing environment presents features that are quite different from the developed economies and even quite different from other developing countries. There are for examples infrastructural problems that are unthinkable in the context of developed economy. Equally government support programmes for SMEs are poorly managed such that intended results are not obtained. There are attitudinal problem on the part of the SMEs operators and officials of government supervisory agencies. All these have direct and indirect impacts on marketing practice of the SMEs in Nigeria. The paper falls back on empirical studies of the lead author, his post graduate and undergraduate marketing students, on SMEs, to illustrate the marketing practice of SMEs in Nigeria, a developing economy. Conclusions are drawn based on marketing practice of SMEs in Nigeria. The authors call on scholars and writers on marketing functions of SMEs, especially in Nigeria to shift to providing empirical works in their writings on marketing functions rather than the present theoretical considerations. This is because research based findings could be used to improve the marketing practice of SMEs.In summary, the primary purpose of this paper is to present research based findings of the marketing practice of SMEs in Nigeria. The usual focus of authors on marketing practice is the big firms that have made it in the market place. The marketing practice of SMEs is usually assumed. However, the SMEs dominate the landscape of all economies, from developed, developing to underdeveloped. Since marketing is concerned with the creation of customer, and this should be the valid basis for the existence of any business organization. It is important that the marketing practice of the organization that dominates in all economies should be investigated, and understood so as to be able to improve on the practice. This paper is divided into four segments, the literature reviews, summary of the findings on empirical investigation of marketing practice of SMEs by the lead author, then findings of undergraduate and post graduate students supervised by the lead author, this is another way of looking at the marketing practice employed by the studied SMEs. Then follows discussion of the findings in the light of the environment and conclusion.
\end{abstract}

\section{The Literature}

\subsection{Strategic Importance Of SMEs In The Developed And Developing Countries}

A number of important factors affecting the SMEs and the conditions that guide the patterns of their development are the main thrust of this literature under consideration here. It is a common practice for discussions on entrepreneurship to focus on SMEs because they constitute the natural habitat of entrepreneurs. There many reasons for this. 
Kilby (1965) stated that with the small enterprise inventions, adaptations and general technological development are possible. Steel and Takagi (1982) noted that small enterprises have potential for absorbing labour, while maintaining output. Other reasons to justify the need for serious efforts in the development of small and medium scale industries are; low level of capital required in their establishment; large number of organizations and the labour intensive mode of operation. Thus, industrial diversification and relatively more balanced regional development afforded; general enhancement of tempo of industrial development is visible among small and medium scale enterprises (SMEs); small and medum scale enterprises often become feeders for large-scale enterprises and also service products made by largescale enterprises.

Fadahunsi (1992) stated that SMEs represents 90\% of the enterprises in ACP (Afican, Carrebean and Pacific) countries. They also provide $70 \%$ of employment opportunities for the citizen and promote indigenous technology. Kuratko and Hodgetts (2001) noted that small businesses employ 53\% of the private workforce and accounted for $47 \%$ of sales and $51 \%$ of private sector gross domestic product GDP. Therefore the SMEs predominate the economy in both developed and developing countries. The reasons for their strategic importance are outlined below;

\subsection{Social-Economic Contributions Of SMEs Firms In Any Economy}

Based on our analysis thus far, it is relevant to summarize the role of SMEs in the social and economic spheres.

A. Social roles of SMEs as agents of social change;

1. Transformation of traditional/indigenous industry into a modern enterprise

2. Stimulation of indigenous entrepreneurship/technology, the entrepreneurs have in their employment potential rivals.

3. Job or employment creation in the community.

4. They provide social welfare service of redistributing wealth and income.

5. Provide leadership for workgroup.

6. Provide for and responsible for motivational system within the firm.

B. Economic roles of SMEs as agent of economic change

1. Marshalling financial resources necessary for the enterprise or mobilization of savings.

2. Bearing the ultimate risk of uncertainty.

3. Providing avenue for dispersal and diversification of economic activities.

4. Utilization of local raw material and human resources.

\subsection{The role of SMEs in Nigerian Economy}

It is noted that the SMEs provides $70 \%$ of employment in the developing countries and this include Nigeria. The relatively higher level of development reported in countries like India, Pakistan, and Singapore for example were contingent in part on the active roles played by indigenous entrepreneurs in those countries which are dominated by SMES

Kilby (1971) listed 13 functions performed by Nigeiran entrepreneurs. Fadahusi (1992) summarized them into 10, these are;

1. Searching for and discovering new information

2. Translating new information into new market, techniques and goods.

3. Seeking and discovering economic opportunities

4. Evaluating economic opportunities

5. Marshalling the financial resources necessary for the enterprise.

6. Making time-binding arrangements

7. taking ultimate responsibility for management

8. Providing for being responsible for motivational system within the firm

9. Providing the leadership workgroup

10. Taking the ultimate risk of uncertainty.

\subsection{Patterns of Government Support Systems For SMEs Development In Nigeria}

Government support systems consist of a number of institutions and agencies established by the government to nurture the small and medium scale enterprises. Some of them include the following; 
1. The National Directorate of Employment (NDE). It was set up by the Federal Government in November 1986 to work out strategies for dealing with mass unemployment in the country especially among school leavers and college graduates (NDE, 1989). The mandate given to NDE is executed within the framework of four core programmes. These are:

a. The small-scale industries and graduate employment, and vocational skills development

b. The agricultural programme

c. National Youth employment and Vocational skills development and

d. Special Public works programme (Okusami, 1990)

2. National Poverty Eradication Program (NAPEP). Former President Olusegun Obasanjo's administration established this body in 2000 for coordinating and monitoring poverty eradication in Nigeria. The strategy, adopted is giving financial and facilities assistance to small scale and micro organizations. It has the following four schemes.
a. Youth Empowerment Scheme (YES)
b. National Resources Development Conservative Scheme (NRDCS)
c. Rural Infrastructural Development Scheme (RIDS)
d. Social Welfare Services Scheme (SOWESS)

3. Small and Medium Enterprises Development Agency of Nigeria (SMEDAN). In his second coming, former President Olusegun Obasanjo's administration put in place a programme that specifically focuses on the small and medium scale enterprises. This programme started actually in the 2004. Its principal function, is to ensure successful establishment of functioning, production units of business organization across Nigeria. The body is to identify individuals or groups with viable business ideas. The agency is to provide such individuals or groups with necessary support of fund, equipment and technical advice. SMEDAN had set for itself the establishment of at least 10 functioning business enterprises in each local government area of the federation.

4. The Peoples Bank. The Federal Government of Nigeria gave policy instrument to the Central Bank of Nigeria to approve the establishment of Community Banks known as Peoples Bank. This is to harness local savings as a source of credit to small scale enterprises. It is a kind of sophisticated thrift and credit society. They are now changed to micro finance institutions.

5. State Government. Many State Governments set up investment corporations or companies. Through such corporations the state government allocates funds on an annual basis for the granting of loans to small and medium scale enterprises.

6. Extension Services Units. The Federal Government in 1964 established Industrial Development Centres (IDCs); These were located in Oshogbo, Owerri and Zaria. They were to provide extension services to small and medium scale enterprises in terms of technical appraisal of loans application, managerial assistance, product development and production planning and control (Jegede, 1990) Later Bauchi was added to make up four zonal centres. Apart from the four zonal centres, there are other 17 satellites and later more were created to have an IDC in each state of the Federation.

The primary objectives of providing support systems are to ease obstacles experience by the SMEs in terms of skills and finance. And also to provide technical advice that can improve their performance in the functional areas including marketing. In addition they serve as method of regulating and controlling the operations of the SMEs.

a. Some of the problems of the government support programmes are in the execution of the programmes. Ogundele (2000) reported that the NDE programme was bedeviled with the following problems; (1) poor monitoring of the programme by the government officials (2) government officials were approving fictitious loans to themselves (3) NDE contractors supplying substandard equipments to beneficiaries of the NDE financial support programmes to SMEs (4) some beneficiaries of the loan provided by NDE defaulted in the payment of the loan while some of them move out of locations used to obtain the loan to avoid being fished out for non repayment of loan. There was also the problem of wrong application of loan provided by NDE by some beneficiaries of the loan. These attitudinal problems listed above are applicable in the cases of all the other agencies mentioned above.

\subsection{Past Empirical Studies Of SMEs In Nigeria}

The works of a number of researchers on SMEs in Nigeria are the focus of this section as a way of looking at their 
performance.

Schatz (1962) and (1964) Schazt carried out two separate studies. The first was Federal Loans Board, which was conducted between 1956 and 1962. The second was on indigenous entrepreneurs who were tenants of the Yaba industrial estate, when it was opened up in 1962. Both studies were on evaluation of performance of indigenous entrepreneurs on the basis of specific assistance and incentives that were provided for them. In (1962) he highlighted three broad categories of determinants of performance of indigenous entrepreneurs. These were; capital; entrepreneur capability; and economic environment. In (1964) he came up with the following problems that affected the performance of indigenous entrepreneurs:- lack of skills that are necessary for the running of modern enterprise-management problem or personal determinant; the formidable nature of the problems in the economic environment, including government economic programmes and policies confronting the entrepreneur - environmental determinants.

Kilby (1965) \& (1971), Kilby examined the origin and performance of indigenous entrepreneurs in the bakery industry in Nigeria. He in (1965) found that indigenous entrepreneurs were vigorous and effective in their perception of opportunities and acquisition of resources in running an organization. He observed, that the major problems were in the realm of management control, and technology. The list of factors that affected the performance of entrepreneurs in Kilby (1971) are;

1. Perception of market opportunities

2. Gaining command over scarce resource

3. purchasing inputs

4. marketing of products and responding to competition

5. dealing with public bureaucracy

6. Management of human relations within the firm

7. Financial management

8. Management of customers and suppliers relations

Harris and Rowe (1966) Harris and Rowe (1966) also examined the origin and performance of indigenous entrepreneurs. They found that capital shortage was not a serious problem or deterrent in the development of various industries. However, they found that the main problems were poor standard of financial management and production control.

Harris, (1968) and (1971) Harris (1968 and 1971) examined the structure and performance of indigenous entrepreneur's organization. The factors that accounted for their emergence and performance were found to include both personal an environmental determinants.

Akeredolu-Ale (1975), this researcher examined the origin and performance of indigenous entrepreneurs. He identified two broad categories of factors that affected entrepreneurs. These were: the environmental factors and the personal factors.

Osoba, et al (1987), the findings of Osoba (1987) and his team of researchers on small scale industries in Nigeria, was in 1982 - 1985. They found that the following factors affected the performance of entrepreneurs; external political legislation; technology; various economic issues; psychological factor in term of individual motivation; education and training; information and counseling support system; management and; cultural environment.

Inegbenebor (1995), he explored the structural elements of SMEs in Nigeria relation to their performance. He found that size was a major predicator of structure even among relatively small enterprises.

Ogundele (2000), the study viewed entrepreneurship as a multidimensional phenomenon. It was found that the processes of emergence, behaviour and performance of indigenous entrepreneurs were separately and in combinations affected not by a single but multiple factors, in ranging degrees. These factors included economic, socio-cultural, ecological, managerial, educational development, experiential, technological, structural, ethical and innovative issues.

Lawal, (2005), Lawal (2005) focused on management practices of SMEs in Lagos State. Results of the study indicate that Nigerian SMEs operators are mostly autocratic and participative.

In the studies sketched out above, marketing functions in most of them are pulled together under economic factor that affect the SMEs. Kilby (1971) however clearly specified the marketing functions of the SMEs ranging from perception of market opportunities to management of customers and suppliers relations. Also Ogundele (2000) study which examined several factors that affect the SMEs focused on the marketing function as reported in Ogundele and Gbadamosi (2000) under the title; Empirical study of marketing strategies of small scale businesses in Nigeria. Therefore most of the studies on SMEs in Nigeria did not consider their marketing practice as a major focus of their studies. It is on the basis of this that the author of this paper encouraged his undergraduate and postgraduate students to concentrate 
their research works on the marketing practice of SMEs. The findings of those studies are reported below under recent research findings of marketing practice of SMEs in Nigeria.

\subsection{Importance of Marketing functions to SMEs}

Marketing function is central to the survival and growth of SMEs. Equally the environments in which the SMEs operate have tremendous impact on their survival and growth. Both of these dimensions are considered in the marketing practice of SMEs under discussion.

Marketing practice as used in the context of this paper is synonymous with strategy. Adeleke, Ogundele and Oyenuga (2008) define strategy as the pattern of major objectives, purposes or goals and essential policies and plans for achieving those goals, stated in such a way as to define what business the company is into or to engage in.

In the focus on the marketing practice of SMEs in this paper, the broad spheres of marketing in terms of product, price, place and promotion, are examined in terms of their separate contributions to the marketing practice of SMEs in Nigeria. Therefore the various components of product in terms of branding, packaging, qualities and others are relevant. Equally pricing practice including credit policy, discounts and other pricing practice are important. Various modes of distribution (place) employed e.g. direct-selling and use of middlemen and promotional practice in terms of advertising, personal selling, sales promotion, publicity and public relations are important. The effective management of marketing practice by small and medium enterprises in these areas determine the success of their operations.

To this end, Owualah (2004) notes that most small business sell their products direct to the final users without the use of intermediaries, this is because they are small and can dispose their products to the people who pass by their workshops. By the characteristics of SMEs which include smallness in share of market within the sector, owner managed and sometimes assisted by family member, not publicly quoted and greater percentage of their raw materials locally sourced, among others, as such, SMEs marketing practices are tailored to meet customers needs with whom they are in very close contact. There is also the happiness of working in the comparatively simple structured environment of small scale enterprises and markets. Their closeness to customers and employees provides potential marketing practice superiority. Added to this is the fact that substantial percentage of the marketing activities of the small scale enterprises are in the wholesale and retailing areas.

Ogundele and Gbadamosi (2006) notes that due to their nature most small scale enterprises are not giving logo corporate identity the significant position it deserves in their marketing strategies. This may be dues to the fact that demand for their products depend on price and selling function does not usually distracts the staff from the main task of production. However, thorough marketing plan is necessary for small business organization in Nigeria because of the volatile nature of Nigeria business environment.

\subsection{Regulatory Environment Of SMEs Marketing In Nigeria}

Ogundele (2000) reported that a major factor in the marketing environment that impacted on SMEs in the food processing industry was the legal ban of imported wheat flour which had spilled over effects on other staple food products in the industry, with consequent effects on marketing practice in those days. One of such consequences was that some of the SMEs started patronizing smugglers of wheat flour in to the country as a survival strategy.

Presently several environmental factors have negative impact on the operators of both small and big enterprises in Nigeria. This is particularly so since the inception of the civilian administration in 1999.

\subsection{Objectives of business regulation and control}

There has been some controversy on the desirability of government regulation and control of business activities. The advocates of free enterprises system argue that non-interference of government in the operations of business enterprises will provide opportunity for creativity, better performance, fair competitiveness, and assured profit. They assert, further that non-interference in the management of private enterprises will create optimal wealth in the best interest of the society.

\subsection{Impacts of Government Policy}

Banjoko (2009) clearly captured the collection of environmental factors that negatively affected the manufacturing 
industry in Nigeria. These include lack of manufacturing friendly environment, frequent policy reversals, spurious levies and changes, infrastructural decay, non or erratic power supply, very poor road transportation system, collapsed rail system, most inefficient port system and menace of smuggling, to mention the crucial ones. The result of the hostile environment as noted by him is that most multinational organization have relocated into other Africa countries and elsewhere e.g. Unilever Nigeria Plc relocated to Ghana, Michelin Tyre Company Ltd transferred production of tyre of France and became major importer of tyres to Nigeria, Nestle Nigeria PIc and Cadbury Nigeria PIc have also been forced to shift $50 \%$ of their operation to Ghana where electricity supply is stable and reliable.

If the Nigerian environment can force big organization to relocate to other countries, the impacts of the environment on the operations of small business organization and their marketing practice can best be imagined.

The end result of the unfavourable regulatory environment is that the SMEs operators see the government and its agencies as uncaring in term of providing supporting infrastructural facilities, and since they cannot relocate outside Nigeria; some relocated to other less stifling environment e.g. from Lagos State to Ogun State. They also employ the strategy of tacit resistance by breaking rules and regulation when ever it is possible e.g carrying out their marketing activities at the close of government official working hours during week days and at weekends. In other cases the costs of providing infrastructural supports by SMEs operators are passed on to the consumers in term of high product prices, that is, for the enterprises who are able to survive the harsh regulatory environment.

\subsection{Specific Infrastructural Problems Of SMEs}

An added dimension of the environmental problems that affect the marketing practice of SMEs in Nigeria is the demolition off buildings and Market stalls that house this category of business enterprises in major cities across the country. The reasons for such demolitions range from illegal occupation of land, change in ownership of land or acquisition for public good. This behavioural pattern stems from the fact that the SMEs sector in Nigeria is populated by micro enterprises driven by the idiosyncrasies of individual business operators. As an example, Okwuofu (2010) reported that traders wept as their shops located at Owode, Oyo town, Oyo state were demolished. At the scene of the demolition there were many riot policemen supervising the exercise. The practice of demolition started since the inception of civilian administration in 1999 at the Federal Capital Territory, Abuja. The wide spread demolishing of structures that house the small business have compounding impacts on their marketing practice. Also, Agboola (2010) reported that the SMEs operators cried out for solution to the prohibitive costs of doing business by SMEs operators in Nigeria. The major reasons for this are government regulatory policy and infrastructural problems noted above. To survive an enterprise must study the environment in which it is operating and the threats and opportunities contained in the environment (Ogundele 2007). Most SMEs business operators do not carry out effective monitoring of the operating environment and therefore they are sometimes taken by surprise when government policies that affect their operations are unfolded.

This particular problem noted above is the product of the attitude of the SME operators on the one hand, some of them believe that they can break the law as long as they are caught, so they engage in on wholesome activities to survive in the market. On the other hand, some of the low level government officials take regular tips from violators of government regulations to provide shield for them. This again is attitudinal problem. The other is that premium is placed on money by some of the SMEs to the neglect of ethical marketing practice

Ford (2000) in respect of Nigeria placed emphasis on tremendous marketing opportunities and also on challenges that seem severe and daunting. Noting that for foreigners to enter Nigeria market based on the problems, emphasis should be placed on using local agents and distributors for successful marketing efforts. This is because the local people understand Nigeria marketing landscape and the marketing practice.

Apart from the researchers on SMEs that are reported above, writers on SMEs in Nigeria have not also given the marketing practices of such organizations the necessary focus. Their writings have been centred on principles that should be adopted not the practice in place. As such the works of Oshagbemi (1983), Udeh (1990) Lawal, Kio, Sulaimon and Adebayo (1998) Owualah (2004) Osuagwu (2006) and Inegbenebor (2006), to mention a few placed their emphasis on principles and expected procedures and not marketing practice. Ogundele (2007) produce a blend of both principles and practice based on his 2000 work on entrepreneurship in Nigeria. Therefore this paper is intended to fill this identified gap.

\section{Contextual Positioning of Marketing Practice of SMEs}

The reports of the marketing practice of SMEs in Nigeria which follows is based on two broad approaches. First, the experience of the lead author based on his study of indigenous entrepreneurs in Nigeria. Second, research findings on 
marketing practice of SMEs by both undergraduate and post-graduate students supervised by the lead author. The students were encouraged to concentrate their research activities on the practice of small business organizations in all functional areas of business so as to provide needed data base. Summary of research findings of selected sample of the student works is presented after the reports of the authors own experience.

\subsection{The Author's Experience of SMEs Marketing Practice: Incidences}

It is necessary to note that the marketing practice employed by entrepreneurs studied by Ogundele (2000) included marketing research, product innovation, and modification, channel adaptation, pricing strategy, relationship marketing and adaptive promotional practice for survival of their organizations.

One of them in the palm kernel oil extracting business in llesa, Osun State, discovered that he was incurring losses when he compared costs of materials with sales proceeds in his operations. He noted that his competitors in the locality were making profits. He carried out a personal marketing research. The result of his finding was that his losses were due to defective palm kernel oil extracting machine supplied to him by National Directorate of Employment (NDE) contractor, not to marketing inefficiency. This particular entrepreneur was a beneficiary of NDE financial support. A new machine was secured through another fabricator. The entrepreneur claimed that the new machine was efficient and he was making more profit than the best of his competitor in the environment. The marketing gain was due to the fact that his improved production system yielded higher output per extracted ton of palm kernel than similar equipment in the locality (Ogundele and Gbadamosi, 2006). The entrepreneur provided a lesson in the close links between marketing research, improved production process and effective marketing performance.

Ogundele (2000) study reported a group of entrepreneurs in Oyo, Osun and Lagos State who employed survival strategy in the 1980s and 1990s, in their marketing practice to diversity from the bakery industry into other food processing operations and marketing. This is an exhibition of octopus phenomenon which is a problem associated with managing growth in the sub-sector. The areas to which they diversified included corn and flour milling, rice and gain processing. These groups of entrepreneurs were as a result able to survive in an environment that was inhibitive.

Another group of entrepreneurs, in Ibadan metropolis, in the bakery industry in the late 1980s and early 1990s, established selling points, as channel of distribution at several locations at Ibadan end of Lagos-Ibadan Expressway. Then, patronage for baked bread in the city of Ibadan was very low. The objectives were to secure patronage from long distant travellers. This marketing strategy is still in operation today and had spread to other segments of the expressway around Ibadan.

There was an entrepreneur in Ogbomoso, Oyo state who employed a combination of relationship marketing in terms of establishing cordial and long lasting relationships with employees and outside clients. Another is total quality marketing management which involves continual improvements in product and service delivery for improved values to the customers. These practice were used to secure competitive advantage over rival organizations. The entrepreneur treated all employees regardless of their relationship with him as internal customers of the organization. They were regarded as members of the same family. The same strategy was applied to external customers. The result was that both employees and customers remained loyal to the organization by maintaining over two decades of unbroken association at the time of the study.

There were other group of entrepreneurs who engage in innovative behaviour as important factor in product development, modification and adaptation in their marketing operations. First, is cassava grater innovator, who produced a proto type grater in the late 1950s. When his invention was successful, women in Oyo town, Oyo state where the inventor was situated refused to patronize his invention. The promotional strategy he employed to break the resistance to his innovation was grating cassava for the women, free of charge initially, he started charging them for grating their cassava when his innovation had taken root in the community.

Another is a case of product modification, whereby an entrepreneur in Igbeti, Oyo State, introduced yellow colouring into his bread production process. He was thus able to secure the patronage of the nomadic Fulani, a substantial market segment in his locality.

There was a particular entrepreneur in Eruwa, Oyo State, who was a technological innovator, employing adaptive innovation, in the production of machines, equipment and spare parts for use in the food processing industry. These entrepreneurs established a number of food processing factories, where his products were tested internally for quality and reliability of performance. He was patronized from different parts of Oyo and Osun States.

In the incidences that were outlined above, the individual entrepreneurs or a group of them that are in collusion as a strategy for managing competition, e.g. the bakers in Ibadan metropolis - sought to maintain differential advantage in 
several ways. These included market segmentation, product adaptation, process improvement, channel cultivation, process improvement, channel and product innovation (Ogundele and Gbadamosi, 2006). The incidences presented above occurred prior and up to 1999, the period dominated by military rule in Nigeria.

\subsection{Recent Research Findings: On SMEs Marketing Practice}

This section presents a summary of major findings of marketing practice by SMEs in Lagos State. It should be noted that Lagos State is mini Nigeria, all the ethnic groups in Nigeria are well represented in Lagos as a former political capital of Nigeria and now its commercial capital. Thus, the finding of the studies being reported here could be regarded as representative of SMEs in Nigeria. The studies whose findings of marketing practice are summarized in Table 1 below were conducted between 2005 and 2009 in a democratic environment in Nigeria. A sample of 38 studies by both undergraduate and post graduate students in Lagos State University, Ojo, Lagos are selected. The major criterion is that the study focused on some aspects of marketing practice by the organizations that were focused upon by the students. The specialization areas of the students' studies are in marketing and business administration.

Thirteen issues are isolated in the selected study. Eleven of them are pure marketing issues, the remaining two of them are environmental issues that affect marketing practice. The pure marketing issues used to structure the discussion that follows after the table involves the followings; Product strategy, ranging from new product development, product line extension, branding, packaging and products of insurance service; General marketing strategy; Promotional strategy; The practice of social responsibility; Relationship marketing; Strategic marketing; Consumer attitude perception; Pricing strategy; Channel of distribution; Market orientation practice and International marketing practice.

The environmental issues affecting marketing practice that are selected are:-

The general environmental factors and Government regulatory policies.

Table 1 below displays the following features: focus of research topics, the activities employed by the small business operators and the marketing practice resulting from such activities.

Table 1: Marketing practice of selected small and medium enterprises or entrepreneurial organizations in Nigeria

\begin{tabular}{|c|c|c|c|}
\hline $\mathrm{S} / \mathrm{N}$ & $\begin{array}{l}\text { Focus of } \\
\text { Topics }\end{array}$ & Activities Employed in General & Marketing Practices \\
\hline 1 & $\begin{array}{l}\text { Product } \\
\text { Development }\end{array}$ & $\begin{array}{l}\text { - Innovation and Process of Introducing the } \\
\text { innovation }\end{array}$ & $\begin{array}{l}\text { - Promotion of regular external constant } \\
\text { advertisement. } \\
\text { - Ensure that product gain consumers acceptance. }\end{array}$ \\
\hline 2 & $\begin{array}{l}\text { Product Line } \\
\text { Development }\end{array}$ & $\begin{array}{l}\text { - Having more than one item on product } \\
\text { line }\end{array}$ & $\begin{array}{l}\text { - Inform consumer of the varieties available in } \\
\text { product offerings }\end{array}$ \\
\hline 3. & $\begin{array}{l}\text { Strategy for } \\
\text { New Product } \\
\text { Development in } \\
\text { Insurance } \\
\text { Industry }\end{array}$ & $\begin{array}{l}\text { - New Product development based on } \\
\text { intense competition. } \\
\text { - Utilize investment capabilities, Attracting } \\
\text { more people to insurance industry. }\end{array}$ & $\begin{array}{l}\text { - Engage in active new Product Development in } \\
\text { insurance industry. } \\
\text { - Well tailored to attract more people to have one or } \\
\text { more policies. } \\
\text { - Increase sales volume, profitability and Investment } \\
\text { capabilities. }\end{array}$ \\
\hline 4 & Product Line & $\begin{array}{l}\text { - Developing a New Product for Current } \\
\text { Market. } \\
\text { - Effective Promotional and Distributional } \\
\text { Activities. } \\
\text { - Environmental Factors }\end{array}$ & $\begin{array}{l}\text { - Innovation by Marketers introduced to the markets. } \\
\text { - Tend to Affect the Operations of Small Scale } \\
\text { Business in term of improved sales volumes }\end{array}$ \\
\hline 5 & Branding & $\begin{array}{l}\text { - Afford Customers the opportunity for } \\
\text { greater varieties of improved Quality } \\
\text { Product. }\end{array}$ & $\begin{array}{l}\text { - Innovative Modification of Brand to Retain } \\
\text { Customer Loyalty. }\end{array}$ \\
\hline 6 & $\begin{array}{c}\text { Brand } \\
\text { Positioning } \\
\end{array}$ & $\begin{array}{l}\text { - Combining all the marketing Mix. } \\
\text { - Distinguishing Competitive Brand }\end{array}$ & $\begin{array}{l}\text { - Exhibiting the quality of the product. } \\
\text { - Effective use of marketing mix elements. }\end{array}$ \\
\hline 7 & Packaging & $\begin{array}{l}\text { - High Price of materials. } \\
\text { - Non Availability of materials }\end{array}$ & $\begin{array}{l}\text { - No Control, Based on Government Regulations, } \\
\text { Most Packaging Materials are imported. } \\
\text { - Adaptation of local packaging materials. }\end{array}$ \\
\hline 8 & $\begin{array}{c}\text { Brand } \\
\text { Positioning }\end{array}$ & $\begin{array}{l}\text { - Brand Name } \\
\text { - Consumer Perception }\end{array}$ & $\begin{array}{l}\text { - Position Helped Shape Perception, but Perception } \\
\text { must match Brand Experience for a Good and }\end{array}$ \\
\hline
\end{tabular}




\begin{tabular}{|c|c|c|c|}
\hline & & $\begin{array}{l}\text { - Packaging } \\
\text { - Brand Patronage } \\
\text { - Brand Performances }\end{array}$ & $\begin{array}{l}\text { Sustains Market Performance. } \\
\text { - Brand Name Appealing and in Tune with Other } \\
\text { Consumer Perceptions }\end{array}$ \\
\hline 9 & Branding & $\begin{array}{l}\text { - Strategic Decision } \\
\text { - Consumer Behaviour }\end{array}$ & $\begin{array}{l}\text { - A Target Market Identified } \\
\text { - To succeed, it requires a lot of Advertising and } \\
\text { Promotion During a Long Period of Time. }\end{array}$ \\
\hline 10 & $\begin{array}{l}\text { Marketing of } \\
\text { Insurance } \\
\text { Services }\end{array}$ & $\begin{array}{l}\text { - Marketing Plans } \\
\text { - Consumer Behaviour } \\
\text { - Marketing Research }\end{array}$ & $\begin{array}{l}\text { - Companies that were marketing oriented that can } \\
\text { survive. } \\
\text { - Government Financial and Management Factors } \\
\text { has Contributed to Poor Responses. }\end{array}$ \\
\hline 11 & $\begin{array}{l}\text { Marketing } \\
\text { Strategies }\end{array}$ & $\begin{array}{l}\text { - Innovation } \\
\text { - Interactive Marketing } \\
\text { - Target Marketing Identification }\end{array}$ & $\begin{array}{l}\text { - Incremental Adjustment to Product/Services. } \\
\text { - Informal Information Gathering. }\end{array}$ \\
\hline 12. & $\begin{array}{l}\text { Marketing } \\
\text { Strategies }\end{array}$ & $\begin{array}{l}\text { - Critical Success Factors } \\
\text { For Enterprise Survival Use of IT. }\end{array}$ & $\begin{array}{l}\text { - Its use enhances organizational Effectiveness. } \\
\text { - Increases and Creates Opportunities. }\end{array}$ \\
\hline 13 & $\begin{array}{l}\text { Marketing } \\
\text { Strategies }\end{array}$ & $\begin{array}{l}\text { - Marketing Mix Use } \\
\text { - Customer Satisfaction } \\
\text { - Customer Expectation }\end{array}$ & $\begin{array}{l}\text { - Promotion and Pricing Policies Adopted to } \\
\text { Dissuade Regular Customers from Easily } \\
\text { Changing to Another Brand. } \\
\text { - Demand Theory. }\end{array}$ \\
\hline 14 & $\begin{array}{l}\text { Marketing } \\
\text { Strategies }\end{array}$ & $\begin{array}{l}\text { - Customer/Client Relationship } \\
\text { - Price Slash } \\
\text { - Marketing Orientation }\end{array}$ & $\begin{array}{l}\text { - Sales Promotion and Advertising were Revealed to } \\
\text { be more Effective. } \\
\text { - It is the Quality of Service and Products that } \\
\text { Promote Cordial Relationship. }\end{array}$ \\
\hline 15. & $\begin{array}{l}\text { Marketing } \\
\text { Strategy }\end{array}$ & $\begin{array}{l}\text { - Customer Expectation } \\
\text { - Globalization } \\
\text { - Customer Orientation }\end{array}$ & $\begin{array}{l}\text { - Putting Customers First to Build Customers } \\
\text { Oriented Skills. } \\
\text { - Understanding of Customer Economics } \\
\text { - Improving the Customers Knowledge and } \\
\text { Customer Connection Technologies. }\end{array}$ \\
\hline 16 & $\begin{array}{l}\text { Marketing } \\
\text { Strategy }\end{array}$ & $\begin{array}{l}\text { - Maintaining the same product and brand } \\
\text { for long }\end{array}$ & $\begin{array}{l}\text { - To cultivate customer continued loyalty. } \\
\text { - Product that are household name tend to } \\
\text { overshadow new product serving some functions }\end{array}$ \\
\hline 17 & $\begin{array}{l}\text { Marketing } \\
\text { Strategies }\end{array}$ & - Product Modification and Adjustment & $\begin{array}{l}\text { - Insurance firms engage in use of multiple } \\
\text { corporate strategies to support existing and dying } \\
\text { product, the result is high cost of operation. }\end{array}$ \\
\hline 18. & Promotion & $\begin{array}{l}\text { - Create more awareness for Company } \\
\text { Product. } \\
\text { - Increase demand of company product } \\
\end{array}$ & $\begin{array}{l}\text { - Periodic sales Promotional activities. } \\
\text { - Improve image of the company through promotion. } \\
\text { - Use of adverting in local media. }\end{array}$ \\
\hline 19 & $\begin{array}{c}\text { Sales } \\
\text { Promotion }\end{array}$ & $\begin{array}{l}\text { - Personal selling } \\
\text { - Sales Promotional Activities as Support }\end{array}$ & $\begin{array}{l}\text { - Use of discount and contest to increase sales and } \\
\text { profit, bell ringing, hired criers. }\end{array}$ \\
\hline 20. & $\begin{array}{l}\text { Promotional } \\
\text { Strategies }\end{array}$ & $\begin{array}{l}\text { - Opportunity to Communicate. } \\
\text { - Transmitting Information. } \\
\text { - Create Awareness }\end{array}$ & $\begin{array}{l}\text { - Personal selling and sales promotion } \\
\text { - Influence the performance of business Activities } \\
\text { positively. }\end{array}$ \\
\hline 21. & $\begin{array}{c}\text { Sales } \\
\text { Promotion }\end{array}$ & $\begin{array}{l}\text { - Brand Switchers } \\
\text { - Brand Loyalties } \\
\text { - Create Competitive Edge }\end{array}$ & $\begin{array}{l}\text { - Why sales Drop After Promotion. } \\
\text { - Cash gift and extra product units on purchase } \\
\text { - Dancing masquerades } \\
\text { - Hire of professional drummers } \\
\text { - Attract Brand Loyalties }\end{array}$ \\
\hline 22 & $\begin{array}{c}\text { Social } \\
\text { Responsibility }\end{array}$ & $\begin{array}{l}\text { - Social Obligation } \\
\text { - Economic And Moral Obligations } \\
\text { - Legal Responsibilities } \\
\text { - Social Responsiveness }\end{array}$ & $\begin{array}{l}\text { - Adds an Ethical Imperative to do those Things that } \\
\text { make society betters and not to do anything that } \\
\text { could make it worse. } \\
\text { - Responding to social demands of community } \\
\text { - Ability to Respond to Social Pressures. }\end{array}$ \\
\hline 23 & $\begin{array}{l}\text { Relationship } \\
\text { Marketing }\end{array}$ & $\begin{array}{l}\text { - High Quality Reliable Customer } \\
\text { Databases Distribution, Demarketing, } \\
\text { Mega Marketing, and Social } \\
\text { Responsibilities }\end{array}$ & $\begin{array}{l}\text { - To Draw Data and Figures Information Depicting } \\
\text { Patterns of Need within the Customer and } \\
\text { Prospect Population. } \\
\text { - Low Emphasis Have Been Placed on Aspect of } \\
\text { Marketing Strategy Variables. }\end{array}$ \\
\hline
\end{tabular}




\begin{tabular}{|c|c|c|c|}
\hline & & & $\begin{array}{l}\text { - Recognizing the Importance of Mutual } \\
\text { Relationship, between firms and the Supplier, } \\
\text { Government, Employers, Customers and The } \\
\text { Community where they operates. }\end{array}$ \\
\hline 24. & $\begin{array}{l}\text { Relationship } \\
\text { Marketing }\end{array}$ & $\begin{array}{l}\text { - Proper Marketing Plan } \\
\text { - Focusing on Customers Satisfaction and } \\
\text { Customers Expectation } \\
\text { - Customer Satisfaction }\end{array}$ & $\begin{array}{l}\text { - Putting Customers at the Centre of the } \\
\text { Organization is a Better Source of Creating } \\
\text { Awareness. }\end{array}$ \\
\hline 25. & $\begin{array}{l}\text { Relationship } \\
\text { Marketing }\end{array}$ & $\begin{array}{l}\text { - Creating and Maintenance of Long } \\
\text { Lasting Relationships. } \\
\text { - Use of Total quality Management }\end{array}$ & $\begin{array}{l}\text { - Developing a Customer Oriented Services System. } \\
\text { - Data Base Marketing } \\
\text { - Developing of Partnerships and Networks. }\end{array}$ \\
\hline 26 & $\begin{array}{l}\text { Strategic } \\
\text { Marketing }\end{array}$ & $\begin{array}{l}\text { - Displaying High Environmental } \\
\text { Perception. } \\
\text { - Swot Analysis } \\
\text { - Customer Satisfaction }\end{array}$ & $\begin{array}{l}\text { - Meaningful and Sustainable Economic Growth and } \\
\text { Development in terms of new product and new } \\
\text { process. }\end{array}$ \\
\hline 27 & $\begin{array}{l}\text { Strategic } \\
\text { Marketing }\end{array}$ & $\begin{array}{l}\text { - Marketing Programmes Development } \\
\text { - Market Segments } \\
\text { - Customer Satisfaction }\end{array}$ & $\begin{array}{l}\text { - Management Control and Integrated Major } \\
\text { Marketing Functions. }\end{array}$ \\
\hline 28 & $\begin{array}{l}\text { Consumer } \\
\text { Attitude } \\
\text { Behaviour }\end{array}$ & $\begin{array}{l}\text { - A New Brand } \\
\text { - Modification of Existing Brand. } \\
\text { - Market Segmentation }\end{array}$ & - Providing new information to create awareness. \\
\hline 29 & $\begin{array}{l}\text { Pricing } \\
\text { Strategies }\end{array}$ & - Price Instability & $\begin{array}{l}\text { - Price of a Product Fixed in Line with the Events in } \\
\text { the Market place. } \\
\text { - Fixing Price with the Intention of Stimulating an } \\
\text { Upward Trend in Sales Volume of Consumer. }\end{array}$ \\
\hline 30 & $\begin{array}{c}\text { Price } \\
\text { Perception }\end{array}$ & $\begin{array}{l}\text { - Substandard Products with High Price. } \\
\text { - Prohibitively High Price Hinder Sales }\end{array}$ & $\begin{array}{l}\text { - Sales Promotion, Price Perception and Product } \\
\text { Quality independently and Jointly Predict } \\
\text { Consumers' Brand Loyalty. }\end{array}$ \\
\hline 31 & $\begin{array}{l}\text { Channel of } \\
\text { Distribution }\end{array}$ & $\begin{array}{l}\text { - Wide Varieties of outlets, large consumer } \\
\text { across the country, Bad state of the Road }\end{array}$ & $\begin{array}{l}\text { - Selecting outlets that are easily accessible in } \\
\text { Lagos State and its environ. }\end{array}$ \\
\hline 32. & Direct Marketing & $\begin{array}{l}\text { - Dearth of Social ammenities and in } \\
\text { efficient technology for distribution. }\end{array}$ & $\begin{array}{l}\text { - Direct marketing involving dancing masquerades } \\
\text { and road side marketing. }\end{array}$ \\
\hline 33 & $\begin{array}{l}\text { Agents as } \\
\text { Channel of } \\
\text { Distribution }\end{array}$ & $\begin{array}{l}\text { - Use of agent in Export Trade. } \\
\text { - Product Price Increases due to agents } \\
\text { use. }\end{array}$ & $\begin{array}{l}\text { - The activities of the agents not regulated. } \\
\text { - Exporter must be extra vigilant }\end{array}$ \\
\hline 34. & $\begin{array}{l}\text { Market } \\
\text { Orientation }\end{array}$ & $\begin{array}{l}\text { - Environmental Analysis } \\
\text { - Customer Focus and Social Responsibility }\end{array}$ & $\begin{array}{l}\text { - Information Gathering Increases Quality } \\
\text { Performance. } \\
\text { - Maintaining Regular Contact with Customers } \\
\text { Enhancing Profitability and The Achievement of } \\
\text { Marketing Management Goals. } \\
\end{array}$ \\
\hline 35 & $\begin{array}{l}\text { Intra-ECOWAS } \\
\text { Trade }\end{array}$ & $\begin{array}{l}\text { - Movement of goods and services within } \\
\text { the West African sub-region. } \\
\text { - Infrastructural Problem as Impediment }\end{array}$ & $\begin{array}{l}\text { - Intense smuggling Activities that Kills Honest } \\
\text { Business men. } \\
\text { - Sub-regional Government Negligence on a wide } \\
\text { scale. }\end{array}$ \\
\hline 36 & $\begin{array}{l}\text { Environmental } \\
\text { factors Affecting } \\
\text { Marketing } \\
\text { Practice }\end{array}$ & $\begin{array}{l}\text { - Legal, Political, Technology Competition } \\
\text { from Local and Foreign Big Organization, } \\
\text { Unsecurity. }\end{array}$ & $\begin{array}{l}\text { - Locating in area not attractive to big organization } \\
\text { challenges to success, cleverly breaking the rules } \\
\text { to survive }\end{array}$ \\
\hline 37 & $\begin{array}{l}\text { Infrastructural } \\
\text { Facilities Impact }\end{array}$ & $\begin{array}{l}\text { - Utilities not available Bad state of the } \\
\text { roads and general insecurity. }\end{array}$ & $\begin{array}{l}\text { - Converting residential apartment for business } \\
\text { purposes on part-time bases. Road Side } \\
\text { Marketing. }\end{array}$ \\
\hline 38. & $\begin{array}{l}\text { Government } \\
\text { Regulatory } \\
\text { Polices }\end{array}$ & $\begin{array}{l}\text { - Constant changes in regulation. } \\
\text { - Inconsistent Policies that hinder effective } \\
\text { marketing plan. }\end{array}$ & $\begin{array}{l}\text { - Breaking rules and regulations sometimes to } \\
\text { survive. } \\
\text { - Engaging in unethical acts against rules and } \\
\text { regulations. }\end{array}$ \\
\hline
\end{tabular}

Source: Developed by the Authors 


\section{Discussion of Table 1}

Product strategy: This ranges from new product development, product extension, branding, packaging and products of insurance services. A focus on Table 1 reveals that nine of the selected studies examined product in term of goods while one considered product in term of insurance service. Again four of them looked at new product development or modification, four treated branding and one was on packaging. Kotler and Armstrong (2004) note that product development is the strategy for company growth by offering modified or new products to the current market segment in the small business sector, Ogundele (2007) notes that a well-organized product development programme might even enable a firm to copy other attractive innovations quickly and profitably, because of the simple and dynamic structure of small business organizations. For SMEs, product is the starting point and most important component of marketing mix. This is because the price, the promotion and the channel are all about the product. It is to be noted that the listed marketing practice around the product are intended to ensure that the product gain customers acceptance and to retain customers loyalty. Ogundele and Gbadamosi (2006) stated that product improvement is a method used by producers to maintain their relative industrial position and provide consumer with the latest in the technique or technology hence the reported use of IT, in Table 1 above as a marketing practice by the small business operator.

General marketing strategy: Seven of the topics examined general marketing strategy which covers all aspects of marketing mix elements. It should be noted that a major activities employed in the marketing practice of the selected studies are; innovation, target marketing, marketing plan, marketing research, market segmentation and several others. The objectives being to analyze the present and future marketing environment of an organization so as to formulate marketing objectives and programmes to achieve the objectives. Hinson, Dadzie and Winston (2009) in respect of Ghana a developing country, based on empirical study reported that manager employed transactional marketing and data base marketing while using prospector, analyzer and defender strategies. They noted that the nature of contemporary marketing practice in Ghana is similar to that reported in developed economies.

Promotional Strategy: Promotional strategy in terms of general promotional programmes and sales promotion were examined by four of the topics selected. Meredith, Nelson and Neck (1991) stated that as small business grows, it must expand its markets, special sales promotions can provide the exposure that the product or service needs to increase sales in new markets. Also advertising can attract potential customers to the business. It is to be noted that most of the promotional activities by small business organizations involves the use of staff of the organization to make sales and make them regular customers. Ogundele (2000) reported that entrepreneurs of his study used selective appeal in advertising for example bakers have different handbills and labels attached to their bread for the purposes of promotion and differentiation.

The Practice of Social Responsibility: One of the topics examined the practice of social responsibility, which Ogundele (2007) described as the obligations which small business organizations owe to their relevant constituencies. This involves doing those things that make the society better, for all small business organizations, are intricately woven together in society cobweb with their environment. They live as permanent member of the local society in which they are located as such they have direct stake in enhancing the quality of life in such environment. But one observes that some of them have to be coerced into discharging the obligation through state or local government legislations. But many of them embark on voluntary contributions to the well being of the society in terms of road maintenance, drilling of boreholes and maintenance of community health centres.

Relationship Marketing: Relationship marketing was examined by three of the selected papers. Relationship marketing, Ogundele (2007) is concerned with creating high level of satisfaction of customers through collaborative efforts of parties involved. These include end use customers, channel members, suppliers, competitors alliances and internal team. The relationship marketing practice is common in the bakery industry because bakers nation wide have very strong union enforcing cooperation on members to enhance quality of service delivery, though there are some bad eggs. In the reported study it was found that the studied organizations developed partnership and network to deliver customer oriented service system.

Strategic Marketing: Strategic marketing practice is the focus of two of the topics with emphasis on customer satisfactory, based on designing effective marketing programmes and appropriate market segmentation. Strategic marketing involves analysis, planning implementation and management of marketing activities (Craven, 1997). It therefore, involves customer satisfaction based on careful analysis and commitment of human and material resources to that end.

Consumer Attitude Perception: One of the studies focused on consumer attitude and behaviour, which is used as basis for product modification and market segmentation. Ogundele (2005) notes that attitudes towards object and 
situation will interact with one another and will thereby result in behaviour that will be influenced differently by the two sets of attitudes. This is to show that attitudes towards a product by the consumer will influence the purchase or non-purchase of the product. Marketing practice has to be designed to positively influence the behaviour towards a product, object of sales, through impacts on attitudes.

Pricing Strategy: Pricing strategy was examined by two of the selected topics, It is reported that price is fixed to stimulate upward demand in the product in one of the works and prohibitively high price hinders sales. One pricing practice of many small businesses is the haggling feature in purchase and sale of most product of small business organization.

Channel of Distribution: Channel of distribution practice was the focus of two of the selected studies. It was found that the use of agents in export trade increased business costs as prices are inflated by the agents. Also small business use wide varieties of channel starting from direct sales to end users and the market intermediaries that are easily accessible to end users.

The use of direct sales to earned users is based on convenience, this is borne of the fact that the SMEs operators are in most cases operating on basis of face - to - face contact with their customers or earned users and they know their needs at intimate level. For the fairly big SMEs, it is not possible to maintain face - to - face contact with all their customers, therefore they employ the services of market intermediaries to minimize marketing operational costs.

Market Orientation Practice: Market orientation of maintaining regular contact is the focus of one of the topic. It should be noted that virtually all small business organization are in regular contacts with their customer. Ogundele (2000) report that the entrepreneur of his study used to communicate with the clients and employees on face-to-face basis and it could vary from $60 \%$ to $80 \%$ of the communication patterns. This ensures regular information gathering that could increase the quality of organization performance. Ellis (2005) in respect of market orientation and marketing practice in developing economy, in the case of China provided linkage between marketing practice and performance but no such link exist for market orientation. Speculating that market orientation may be come important over time as market in perfection diminish and information between suppliers and customers begins to flow freely. And that significant antecedents to market orientation for developing country firms were customers and market located outside the home market.

International Marketing: One of the selected studies examined international marketing in the West African Subregion. The focus is the Economic Community of West African States (ECOWAS). Meredith, Nelson and Neck (1991) stated that exporting may provide new markets for small business products. They advised the small business operators to seek advice from government agencies on available opportunities. There is a very high rate of smuggling activities which is killing enthusiasm of honest small business operators in embarking on international marketing from Nigeria. Williams (2006) in respect of Trinidad and Tobago note that most SMEs will remain focused on the local market, and that those that are likely to thrive and expand are the ones that embrace the export challenges and are prepared to adopt new technology, develop new information system and device innovative product that are globally competitive.

General environmental factors: The environmental factors that affect marketing practice was the focus of two of the selected studies. Meredith, Nelson and Neck (1991) stated that the success of small business can be greatly affected by factors outside the owner's control, the factors to which the entrepreneur must respond. The small business may not be able to avoid their influence. Their impacts can be lessened if the small business operators act quickly and effectively. An elaborate picture of the environmental problems confronting business organization in Nigeria was painted in the segment on literature review. It will not be repeated here. However the demolition of market stores and buildings that were erected illegally had resulted in rise in the size and spread of road side marketing. Another is the opening of marketing activities in prohibited location after the close of official working period by government employees who are supposed to prevent such activities. E.g from 6pm upwards in week days and from morning to evening on week ends, that is Saturdays and Sundays.

Ford (2000) examined marketing practice in Singapore and reported that Singapore is highly affluent and matured customer goods society. The advanced telecommunication infrastructure makes Singapore a fertile ground for sophisticated marketing tools and techniques. In respect of China, emphasis was placed on political instability and infrastructural limitations. He emphasized the need for patience on the part of the marketer before being fully accepted and getting the green light. This is characteristics of Asian market.

Government Regulatory Policy: One study examined the impact of government regulations on small business. It lamented the negative impact of erratic changes in government policies and regulations, resulting in unpredictable marketing environment. Ogundele (2000) reported that entrepreneurs of his study embarked on act of indiscipline of smuggling to survive due to very harsh legislations at the time. 


\section{Case of Internal Products Inventor}

Another example of product development and management is reported by Ogundele (2007), in respect of Abiola Akingbade, who created and invented an internet formula for wealth creation and social security. The inventor, then a 30 years old, Ilesha born graduate of accounting from University of Ado-Ekiti. The JLH formula as stated by the inventor is a wealth creation and social security formula, it is independent, flexible and practical solution to wealth generation and distribution with the use of the internet. The inventor stated that formula was created with the hope that it will be driven by the organized private sector of Nigeria and West Africa Economy.

Implementation Strategy: The inventor notes that the implementation strategy for the formula is to form business partnership and strike licensing deals with Information Communication Technology (ICT) companies, telecommunication companies, hospitals, petroleum marketers and several others (Amatus, 2007).

Unique Service: The investor notes that uniquely, four wealth processing cards and metal box packaging are the tools for the implementation of the content of the first of its kind formula. That a full proof marketing and sales strategies have been drawn up, based on pricing, packaging, promotion, target, incentives, assets building and social security concept. It is known as mega seed marketing concept safety measures/research development.

The formula and the implementation is created around the best, simple and available information and communication technology application for web based enterprise software. The funding requirements include; web based enterprise software development, debit cards and scratch cards development, development of processing data, portable terminal, packaging, promotion, and publicity as well as other logistics.

\subsection{Challenges}

The challenges faced by the investor are both environmental and attitudinal these are:

1. Securing government approval before it could be implemented.

2. Securing approval of some relevant authorities.

3. Securing the patent in 2006 .

4. Securing enterprise software development, partnership with banks, insurance companies and other entities.

\subsection{Path To Success}

The inventor stated that, initially all efforts at getting sponsors failed woefully. He later went solo and proceeded to implementation state of the project. It was after building the website and completing other necessary starting requirements that the inventor started receiving calls for sponsorship and partnership.

\subsection{Benefits}

The inventor stated that the formula is also a mega wealth creation and distributive system. It would revolutionize Nigeria and West Africa Economy by creating new awareness and continuous profit. Added advantage is that the implementation tools are already in use in Nigeria and West Africa (Akingbade, 2007). Ogundele (2007) and Ogundele, Hassan and Okafor (2009) reported the attendant problems with E-marketing in Nigeria which include unethical behaviour and process manipulation.

\section{Conclusion}

Several combinations of marketing practice are being employed by small business operators to gain differential advantage. These include product development, product innovation, process improvement, trademark, trade name, patent, quality, package, colour, design, conditions of sales, drumming, dancing masquerades, bell ringing, hired cryer etc. The Igbeti baker, in Oyo state used colouration as a mark of product differentiation. Also the Modakeke food enhancer producer in Osun State, reported earlier on had a patent for his product. The food enhancer producer also used market segmentation by selecting a group of customers with relatively homogenous demands from a total customer group, which is heterogonous in the aggregate.

Ogundele and Gbadamosi (2006) note that process improvement is a more permanent and rewarding development which provide differential advantage. The palm kernel oil producer in llesha, Osun state, is a good example in that respect. Innovation in product, process and marketing arrangement are steps to gain advantage in new market or 
minimize the threat of competitors. The entrepreneurs in Ogundele (2000) study and the report of the marketing practice to small business organization contained in column III in Table 1 and the case of internet product inventor indicate innovative behaviour in terms of product, process, marketing, administration and inter personal relationships.

Therefore, based on the case and incidences provided above and the evidences of research findings contained in Table 1, Nigerian entrepreneurs in small and medium enterprises employed several combinations of marketing practice to survive in the external marketing environment that was described as unfriendly at the beginning of this paper. The practice cover all four key components of the marketing mix elements namely product, price, place and promotion. These marketing mix planning is important for enterprise survival and success.

In respect of product, it is expected that during the product life, enterprise will normally restructure its marketing practice several times. This is based on the changes in economic conditions, results from competitions new products launches and the fact that buyers requirements and interest are redefined, declines also occur in the sales of most product forms and brands of small business enterprises. This can be traced to competition from both domestic and foreign producers, advance in technology and shift in consumers taste.

The shift in taste is illustrated in the case of bread consumers in Ibadan metropolis, which led bread baker to establish selling points around the Ibadan- Lagos Expressway. When product reach a stage of decline in sales, business organizations can use several marketing practice to relocate in the market place. These range from increasing or maintaining the firms investment level, removing unprofitable customer group, as in the case noted above, or disinvesting the business quickly by disposing some assets. The firms strength and the situation in the industry will dictate appropriate strategy for a particular firm.

When product management is considered for small business organizations in Nigeria, they work hard to establish respected brands. Typical examples are provided in the case of the manufacturer of baby food enhancer in Modakeke, Osun State, Cassava grater producer in Oyo Town, Oyo State and the Eruwa Equipment manufacturer in Oyo State.

Concerning pricing practice, small business operators in Nigeria employed different pricing strategies. These include quality discount employed as survival strategy. Another practice by manufacturers of bottled water and some bread baker is to give special incentives to distributors who carry only their products or make the product the major item in their channel. Small business operator can hardly afford the dangerous practice of price war, based on the very high level of competition and sensitivity to price adjustments.

Several distribution channels are available to small business enterprises. However many of them employed direct distribution to the finial consumer or customer. In addition, situations compel some of them to make use of market intermediaries particularly the relatively big ones.

The promotional practice used by Nigerian Small business enterprises, mostly are personal selling and sales promotion, compared with other promotional elements. The personal setting, based on the face-to-face interaction with prospective purchasers is most common and this should be expected as reported by (Ogundele 2000). The small business operator also employs sales promotion, which involves the use of short-term incentives to encourage trail and purchase of product or service. They also use relationship marketing, as contained in Table 1 above, this is employed to sustain customer loyalty. Ogundele and Gbadamosi (2006) reported the use of market segmentation which involves dividing a potential market into several submarkets, with each making up a homogenous group of consumer, and selecting one or more segments as target market to be reached, with specific marketing mix, is prevalent among Nigerian small business operators. The practice contained in Table 1 confirms this position.

Finally, it is clear that Nigerian Small business enterprises owners use various marketing practice ranging from, new product development, process development, process adjustment, segmentation, price discrimination, direct distribution, personal selling, sales promotion, relationship marketing, electronic advertisement and other uses of IT, among the marketing practice. However the effective use of public relation required to be explored better for the benefit of small scale enterprise. Also the problem of unethical behaviour in the use of e-business, including marketing, requires appropriate action by both the business operators and the law enforcement agents in Nigeria. Scholars in Nigeria and elsewhere in developing countries should shift the focus of their writings on marketing to research based findings than theoretical considerations.

\section{References}

Adeleke, A, Ogundele, O.J.K and Oyenuga, O.O (2008) Business Policy and Strategy 2nd ed. Lagos: Concept Publications Ltd. Agbonifoh, B.A. (2006) Marketing for the Small Business in Inegbenebor A.U (ed) Fundamentals of Entrepreneurship pp 131 - 150 , Lagos: Malthouse Press Ltd.

Agboola, T. (2010) SMEs Operators say Cost of Business is Rising, The Nation, Vol. 5, No. 1301, Thursday 11, p. 23. 
Akingbade, A (2007) This man has invented a formula for wealth creation, as reported by Amatus, A. (2007), Daily Sun, Monday, March. 12, p. 16.

Akeredolu-Ale, E.O (1975) The Underdevelopment of Indigenous Entrepreneurship in Nigeria, Ibadan: University Press

Amatus, A. (2007) This Man has Invented a Formula for Wealth Creation, Daily Sun, Monday March 12, p 16.

Banjoko, S.A. (2009) Nigerian Manufacturing Sector; Bumpy Past and Shaky Future what Options for Survival, Inaugural Lecture Series 2009, University of Lagos, Akoka, Lagos.

Ellis, P.D. (2005) Market Orientation and Marketing Practice in a Developing, European Journal Marketing, 39, (5/6) 629 - 645

Fadahunsi, O. (1992) Entrepreneurship and Small Industry Development in the Common-Wealth; An overview, Nigerian Management Review vol.7.No.2, Pp $443-454$

Ford, J.B. (2000) Marketing in Emerging Countries, in Warner, M. (Ed.) Regional Encyclopedia of Business and Management: Management in Emerging Countries, vol. , 142 - 153.

Harris, J.R (1968) The Nigerian Enterprises in printing Industry, Nigeria Journal of Social and Economic Studies, vol. 10, No.2, Pp 213 227

Harris, J.R., (1971) Nigeria Enterprises in Industry, in P. Kibly (Ed) Entrepreneurship and Economic Development, New York. The Free press, Vol.10,No2; Pp. $215-227$

Harris, J.R. and Rowe, M.P., (1966) Entrepreneurship Pattern in Nigeria Saw Milling Industry, Nigeria Journal of Social and Economic Studies, vol.8, No.1 Pp. $67-111$

Hinson, R., Dadzie, K. and Winston, E. (2009) The challenging nature of contemporary marketing practices (CMP) in Ghana: A test of the Miles and Snow Strategies Typology, in Simon, S. (Ed.) Repositioning African Business and Development for the 21st Century, 547 - 557, Proceeding of the 10th Annual Conference IAABD.

Inegbenebor, A.U. (2006) Fundamental of Entrepreneurship, Lagos: Malthouse Press Ltd.

Inegbenebor, A.U. (1992) Size, Structure and performance of Private Nigerian manufacturing Enterprises, in A.T. Ojo (Ed) Management of Small and Medium Scale Enterprises in Nigeria (Pp. 45 - 57) Ikeja: Pumark Nigeria Limited.

Jegede, C.I (1990) The Development of Small and medium Scale Industry in Nigeria, Management in Nigeria, vol. 20. No 39 - 53.

Kilby, P. (1971) Entrepreneurship and Economic Development, New York the Free press.

Kilby, P. (1965) African Enterprise: The Nigeria Bread Industry, the Hoover Institution on war, Revolution and peace, Standard University.

Kotler, P and Armstrong, G. (2004) Principles of Marketing 10th ed Delhi: Pearson Education.

Kuratko, D.F and Hodgetts, R.M (2001) Entrepreneurship: a contemporary approach 5th ed. New York; Harcourt Inc.

Lancaster, G and Massingham, L. (1988) Essentials of Marketing, pp 1-16 U.K: McGraw - Hell.

Lawal, A.A, Kio, J.S., Suliamon, A.A and Adebayo, O.I (1998) Entrepreneurship Development in Small Scale Business, Lagos: Ade-Olu Printing Press Ltd.

Lawal, A. A,(2005) Managements Practices and organizational effectiveness in Nigerian small and medium enterprises (SMEs) in Lagos State, Unpublished Ph.D Thesis, University of Lagos, Akoka.

McCarthy (1977) Basic Marketing 5th Ed, Illinois: Richard D. Irwin Inc.

Meredith, G.G. Nelson, R.E. and Neck P.A (1991) The Practice of Entrepreneurship, Lagos: University of Lagos Press.

Ogundele, O.J.K. (2007) Introduction to Entrepreneurship Development, Corporate Governance and Small Business Management Lagos: Molofin Nominees

Ogundele, O.J.K (2000) Determinants of Entrepreneurial Emergence Behaviours and Performance in Nigeria, Ph.D. Thesis University of Lagos, Akoka, Lagos.

Ogundele, O.J.K and Gbadamosi Ayantunji (2006) Empirical Study of the Marketing Strategies of Small Scales Businesses Lagos Organization Review Vol. 2 No 3 January - March, pp 80-88.

Ogundele, O.J.K. (2005) Fundamentals of Consumer Behaviour, Lagos: Molofin Nominees.

Ogundele, O.J.K, Hassan, A.R and Okafor, E.E (2009) Strategies for Restoration of Moral Health in Nigeria Organizations: A Path to National Development, Journal of Social Sciences, JSS, 675, Vol. 18, No. 2, pp. 103-111, www.krepublishers.com, Delhi: India.

Okunsanmi, D. (1990) The Project on Site as at 1st of May 1990 Report of the Site Monitoring Officers of Small Scale Industries Department all over the Federation.

Okwuofu, O. (2010) Traders Weep as Oyo Demolishes Shops, The Nations Vol. 5, No. 1286 Wednesday January 27, p.6

Oshagbemi, T.A. (1983) Small Business Management in Nigeria, Lagos: Longman.

Osoba, M.A (1987) Towards the development of Small Scale Industries in Nigeria in M. A Osoba (Ed) Towards the Development of Small Scale Industries in Nigeria (Pp. 8 - 24) Ibadan: Rosprint Induatrial Press Ltd., Nigeria Institute of Social and Economic Research.

Osuagwu, L. (2006) Small Business and Entrepreneurship Management Lagos: Grey Resource Ltd.

Owualah, S.I. (2004) Entrepreneurship in small Business Firms, Lagos: G-mag Investments Ltd.

National Directorate of Employment (NDE), (1989) Entrepreneurship Development Programme for Youth Corps Members.

Schatz, S. P., (1964) Aiding Nigerian business: The Yaba Industrial Estate, The Nigerian Journal of social and Economic Studies, vol.6, No. 1, pp:199-217.

Schatz, S. P., (1962), Obstacles to Nigerian Private Investment, The Journal of Social and Economic Studies, vol.4,No.1,Pp 66-73

Steel, W.F, and Takagi V. (1983), Small Enterprise Development and Employment Output Trade Off, World Bank Reprint Series No. 305 Udeh, J.O (1990) Entrepreneurship. A Practical Guide to Developing and Managing your Own Business, Jos: Jons and Lors Publication. 
Williams, E.S. (2006) Supporting the Growth of Small and Medium Enterprises, Nova Committee of Trinidad and Tobago Chamber of Industry and Commerce, Central Bank of Trinidad and Tobago, 1-9. 